\title{
Governmental Regulation and Support of Agro-Industrial Complex: Situation, Problems, Prospects
}

\author{
Efimov A.B.* \\ Department of economic theory and world economy \\ Voronezh State Agricultural University after Emperor Peter \\ the Great \\ Voronezh, Russia \\ E-mail: vlad07_82@mail.ru
}

\begin{abstract}
The purpose of the study is to analyze the current state, problems, and prospects of the governmental regulation of the agro-industrial complex of the Russian Federation. The study revealed the need and importance of state support for agricultural producers in the current economic conditions. The Russian Federation has created a regulatory framework that substantially controls the activities and development of agriculture and agro-food markets. The natural and productive potential of Russian agriculture is rated high, despite a number of identified development problems; however, domestic and foreign practice shows that without control and support from the state at all level of government this potential can not be fully realized. The purpose of the state support for agriculture is to protect the economic, and especially food security of our country. For agricultural producers and agro-food markets, direct, indirect, and intermediated forms of support are applicable. Another important condition for solving the problems of the agricultural sector is the elimination of differences in the living standards and living conditions of the rural and urban population. There is an urgent need to determine the optimal combination of the state regulation and the market levers in the agricultural economy. Such an optimum has not been theoretically found or practically implemented until now. As a result, it was concluded that there is a need to form a system of indicators to assess the effectiveness of such support, and on its basis, a set of measures that use the entire spectrum of direct, indirect, and intermediated influence on the agro-industrial complex to obtain the maximum and sustainable positive effect.
\end{abstract}

Keywords - agro-industrial complex, governmental regulation, state support, food security, social development of rural areas.

The agro-industrial complex is recognized as a strategically important group of sectors of the national economy and the basis for ensuring the general security and food independence of the state, which operates in conditions of increasing competition from the foreign producers, whose commodity products are heavily subsidized from the budgets of their countries; which is accompanied by the increase in imports of food, raw materials, semi-finished products, and processed products from agricultural raw materials, as well as machinery and equipment for agricultural production.

\author{
Stashevskiy V.V. \\ Department of organization of production and \\ entrepreneurship in agro-industrial complex \\ Voronezh State Agricultural University after Emperor Peter \\ the Great \\ Voronezh, Russia \\ E-mail: vlad07_82@mail.ru
}

The development of the processes of Russia's integration into the global world economy justifies the need to establish an effective mechanism for state regulation of both agricultural production and foreign economic activity in the agricultural sector at the national and regional level, based on the innovative component and aimed, on the one hand, to realize Russian national interests and food security of the country, and on the other hand, for the quick and effective integration of Russia into the global agricultural and food market [8]. Whether Russia will actively export surplus of the agricultural products or, on the contrary, import products that it can not or does not want to produce domestically; whether it will be an active participant in the market of finished food products, semi-finished products, raw materials or means of production, it will not be able to do without competition and interaction with foreign partners and rivals [3, 9].And the effectiveness of such interaction, in turn, requires recognition of the need for state regulation and support of the agroindustrial complex, study of the foreign experience of such support and selection of the most effective and suitable examples for Russian practice, their reasonable adaptation and careful perception, as well as the monitoring the effectiveness of the application and adjustment of the measures as needed.

The Russian agro-industrial complex should take its place in the global economy, focusing on the development of production of such types of products for which it has pronounced comparative advantages. Many facts testify to the high potential of the Russian agro-industrial complex: $2.2 \%$ of the world population live in Russia, there is also $8.9 \%$ of the world arable land, $2.6 \%$ of pasture and forage land, $20 \%$ of the world's fresh water reserves, $8.3 \%$ of the global production of mineral fertilizers. Nevertheless, achieving a high level of competitiveness of Russian-made agro-food products is impossible without the formation and systematic implementation of a well-thought-out and focused state policy, both at the federal and regional levels.

Recently, the dynamics of agricultural production in the Russian Federation showed certain positive trends, and if in crop production this fact can be partly attributed to the influence of climatic factors affecting the conditions of crop growth and, accordingly, productivity, then in animal 
husbandry the positive dynamics is the results of the efforts of the state and economic entities.

TABLE I. INDICATORS OF THE DYNAMICS OF THE AGRICULTURAL PRODUCTION IN THE RUSSIAN FEDERATION [1]

\begin{tabular}{|l|c|c|c|c|}
\hline \multicolumn{2}{|c|}{ Indicator } & \multicolumn{4}{c|}{ Years } \\
\cline { 2 - 5 } & $\mathbf{2 0 1 5}$ & $\mathbf{2 0 1 6}$ & $\mathbf{2 0 1 7}$ & $\mathbf{2 0 1 8}$ \\
\hline $\begin{array}{l}\text { Nominal value of GDP produced in } \\
\text { agriculture, bln rubles }\end{array}$ & 2898.7 & 2963.0 & 2909.3 & 2883.4 \\
\hline $\begin{array}{l}\text { Indicesofthenaturalproductionvolumein } \\
\text { cropfarming, \% of the previous year }\end{array}$ & 103.1 & 107.8 & 103.3 & 98.5 \\
\hline $\begin{array}{l}\text { Indicesofthenaturalproductionvolumeina } \\
\text { nimal breeding, \% of the previous year }\end{array}$ & 102.2 & 101.6 & 102.6 & 101.1 \\
\hline
\end{tabular}

As a part of the implementation of the national policy objectives in the agricultural sector, the Government of the Russian Federation has been taking measures for the sustainable development of the agro-industrial complex for several years now. The Russian Federation has long established the regulatory framework that controls certain aspects of the activities and development of agriculture, but has not formed the conditions for accelerated innovative development of the agricultural sector of the country's economy as a whole.

The task of the state support for agriculture is to eliminate the observed differences in the living standards and living conditions of the rural and urban population. The state support of the agricultural sector in both a liberal and a regulated market economy is an objective necessity [14]. Agriculture, due to its inherent sectoral characteristics of functioning, can not receive income from the sale of products, sufficient not only to cover production costs, but also for expanded reproduction and innovative development, preservation of the natural fertility of the land and the development of the sociocultural sphere in rural areas.

The system of the state support for agricultural production and the activities of agricultural producers is formed on the basis of the implementation of certain principles, among which N.F. Vernigorlists five [15]:

- The same degree of accessibility of the elements of the support system for all entities;

- targeting of the state support;

- Existence and the equal accessibility of the guarantees of the state support;

- target nature of the receipt and use of the budget funds;

- Effectiveness of the use of the budget funds.

In the arsenal of the government there are three main forms of the state support [10], which in relation to agriculture should be represented as follows:

1.Direct (this should include direct budget payments: direct subsidies, credit subsidies, compensation for part of the costs of agricultural insurance, etc.) form which is the budget support for agricultural producers, directly affecting their financial and economic activities.
2. Indirect (in this case, budgetary funds can only have a stimulating character: preferential taxation, purchases of agricultural and agro-industrial products for the state needs and the formation of state reserves, interventions and other measures) form suggests the impact on agribusiness entities and the results of their financial and economic activities of the state and regional governments which uses indirect methods.

3. Intermediated (impact through organizational and economic measures and mechanisms that are often not directly related specifically to the agricultural sector of the economy: for example, stimulating and encouraging the achievements of agricultural science, supporting and replenishing the capital of Rosagroleasing OJSC and Rosselkhozbank OJSC, implementation of federal programs and national projects) one is the form of support carried out through indirect forms, mainly of a program-oriented nature, the direct action of which is not aimed at the agricultural sector of economies and countries, but the results of which will ultimately affect it.

Many developed and developing economies of the world actively apply themonetary policy tools, labor market regulation methods and approaches, forecasting and programming, inter-farm and inter-district regulation and interregional ties in the process of state regulation of the market economy, including in order of the development of agriculture and related industries.

The economic reformation has led to the significant changes in the structure of the agro-industrial complex of Russia. However, until now it has practically not affected the economic efficiency of the production activities of its entities. Despite the expiration of the implementation of the priority national project "Development of the agro-industrial complex", as well as the State program "Development of agriculture and regulation of the markets for agricultural products, raw materials and food for 2008-2012", according to some researchers, the expected effect of this complex of macroeconomic measures have been achievedneither during that period nor till now. Profitability in the industry is significantly lower than in almost all other sectors of the economy; high accounts payable of agricultural producers remain as well. The restraining factor in the development of the domestic agro-industrial complex should also be recognized as the maintaining of significant lag in the living standard of the rural population, as a result of which the settled rural territories disappear and settlements become empty.

T.M.Polushkina notes [11] that the crisis in agriculture in the modern Russia has lost its classical cyclical nature, in which the potential for the subsequent phase, growth, is formed and accumulated at the recession stage. Understanding of the crisis in the agrarian sector of the Russian economy as the one that has become protracted and sustainable and, in fact, threatens the country's national economic security, currently determines the state recognition of the agrarian policy as one of the most important components of the national economic policy and understanding of its goals as priority. Under these conditions, there is an urgent need to find a reasonable and justified combination of the state regulation and the market levers in the economy of agriculture and related industries, to develop the theory and improve the 
practice of government influence and regulation of macro- and microeconomic processes in agriculture. It should also be recognized that at the moment such an optimum has not been theoretically found, much less practically realized.

Nowadays, the main reasons for the poor manageability of economic processes by both federal and local authorities in the agro-industrial complex are [2]:

- significant degree of self-removal of the state from the regulatory functions, especially from the regulatory impact in the field of inter-sectoral and inter-company relations, as well as from the problems of equivalence of exchange between agriculture and industry;

- distinct mismatch between the actual management system, the requirements of the market economy and the regional specifics, and the nation's tasks to protect its food security;

- lack of a clear allocation of stages in the implementation of the reforms in the agricultural sector and the relationship between them;

- underestimation of social factors.

Among the directions of planning and implementing the measures to overcome the crisis phenomena in agriculture and the agro-industrial complex as a whole, especially after our country joined the WTO, E.F.Kartashov notes the following [7]:

1. General measures aimed at leveling the main threats that are complex in the case of Russian agriculture and are expressed in the technical and technological lag and the investment unattractiveness of the agro-industrial complex as a whole.

2. Protectionist measures for the domestic Russian market, acquiring both economic and political importance in the context of the country's accession to the WTO. Protection against the competition with imports is especially important for the livestock producers, although facilitating the entry of foreign competitors into the Russian market may affect the crop production [6].

3. Events ensuring the development of the domestic market for agro-food raw materials and finished products, as well as export industries. In terms of expanding sales markets, one can propose supporting the presence of competitive agro-food products in foreign markets, as well as diversifying its use [5].

Agriculture is one of the low-profit sectors of the economy. In most countries of the world, this industry exists thanks to the state support and subsidies and is characterized by an extremely long investment cycle: from a year in arable farming to a minimum of ten years in horticulture, if we mean pome crops and stone fruits. In recent years, the situation in Russian agriculture has been changing for the better, albeit slowly (Table 2). Firstly, due to the active state presence, regulation, and support of the industry, transparency, and sustainability of the industry are growing, and consequently, the attractiveness of the direct investments in it. Secondly, the investors began to pay attention to the agricultural sector in the face of rising prices in the international food markets, increasing the importance of agriculture as a sector of the global economy as a whole [13].

TABLE II. INVESTMENT IN THE FIXED ASSETS OF RUSSIAN AIC [7]

\begin{tabular}{|l|l|l|l|l|}
\hline \multicolumn{1}{|c|}{ Indicator } & \multicolumn{4}{c|}{ Years } \\
\cline { 2 - 5 } & \multicolumn{1}{|c|}{$\mathbf{2 0 1 5}$} & $\mathbf{2 0 1 6}$ & \multicolumn{1}{c|}{$\mathbf{2 0 1 7}$} & \multicolumn{1}{c|}{2018} \\
\hline $\begin{array}{l}\text { Investment in the fixed assets } \\
\text { of AIC, mln rubles }\end{array}$ & 296035.9 & 364685.3 & 374722.4 & 423194.4 \\
\hline $\begin{array}{l}\text { Tractors, unitsper 1000 } \\
\text { haofthearableland }\end{array}$ & 3.3 & 3.1 & 3.0 & 3.0 \\
\hline $\begin{array}{l}\text { Grainharvesters, unitsper 1000 } \\
\text { haofthe area sown to cereals }\end{array}$ & 2.4 & 2.4 & 2.3 & 2.4 \\
\hline
\end{tabular}

The main source of financing the investment in the fixed assets is still the own funds of the companies (about $30 \%$ of investments). The destabilizing factor in the growth of the investment activity is the discrepancy between the federal and regional laws [12]. The macroeconomic conditions for the functioning of agriculture have worsened and in connection with the introduction of international sanctions against the Russian Federation, for example, only in 2014, investments in fixed assets already decreased by $5.5 \%$. Problems such as stated below also remain relevant:

- the process of technical and technological modernization of the industry is extremely slow, the rates of updating the main types of agricultural machinery remain extremely low;

- in this regard, the share of costs for repair and maintenance of the equipment is growing, while its productivity is decreasing;

- leasing of agricultural machinery is still extremely poorly developed;

- the migration outflow of the population continues, which exceeds its natural increase;

- the qualitative parameters of the rural population are also deteriorating: the average age is growing, young people after receiving education remain in the cities;

- reforming of the sphere of preschool and school education and healthcare in rural areas has led to the deterioration in the situation in the social sphere in many regions of the Russian Federation.

In 2015, the amount of subsidies from the federal budget for the implementation of the Federal Target Program "Sustainable Development of Rural Areas for 2014-2017 and for the period until 2020" was reduced by $10 \%$ [1]. In connection with the fall in the world oil prices and the already widely discussed sequestration of the state budget, the further reduction in the volume of financing from the federal budget in 2016-2017 took place as well, which, in turn, caused underfulfillment of the program indicators, outflow of young, educated and promising personnel from the agricultural sector and especially the social sphere of the village, reducing the resources of the innovative development of agriculture and related sectors of the economy [4].

No less problematic to this day remain the formation of a unified methodology for the distribution and efficient use of 
the budget funds allocated to support the domestic agriculture, as well as assessing the effectiveness of such use.

Different approaches are proposed to justify the distribution and correctly assess the effectiveness of the use of the funds allocated from the budget to support agricultural production, including using the following parameters and indicators:

- the total volume and share of the tax collection and their relationship with the volume of assistance and compliance with the government guarantees;

- development of the agriculture as a whole and its subsectors, evaluated by the dynamics of the efficiency coefficients of the use of various resources; profitability of certain types of products and the activities of companies in general;

- study of the proportions in the application of the analyzed instruments (subsidies, loans, tax benefits, etc.) in monetary terms (sometimes taking into account weighting factors for direct and indirect support methods) and their comparison with the gross agricultural output and financial results of the companies, producing it;

- determination of the coefficient of protection (which can be calculated as nominal and as effective one), as well as the effective coefficient of subsidies through the direct and indirect subsidies and taxes in agriculture;

- assessment of the state support for producers through the assessment of the effectiveness of its individual areas and results, for example, the degree of support for the market price of individual products, especially of the strategic importance, narrowing the gap between domestic and world prices, and price disparity, through the indicator "the degree of adaptation of agricultural producers to market relations";

- assessment of the degree of favorable investment climate in the industry as a whole across the country and by region, the expansion of the credit opportunities for agricultural producers, the availability of other sources of financing;

- use of the norm of need for subsidies by product groups, industries, land quality, size of companies, etc.

Meanwhile, the lack of a recognized (and adopted by the government) methodology for assessing the need for budgetary support for agricultural enterprises, as well as evaluating the effectiveness of their distribution and application, makes planning and control in this area difficult. As a result, situations of inefficient cost overruns, transfers of the assistance fromthose who are most in need of it to other entities, as well as the infusion of funds into those areas where, in principle, they can not bring the expected impact, are possible.

Thus, we come to the following conclusions. State regulation of the economic processes in the agricultural sector and support for agricultural producers, and in some cases also for processors, resellers, and manufacturers of the means of production for agriculture, are objectively necessary and typical not only of the Russian Federation. The agriculture of our country, despite the protracted crisis, has natural, resource, production, investment, and innovative potential for the development and competitiveness of both goods and companies. However, the domestic and foreign practice shows that without the state control and support at the federal, regional, and local levels, this potential can not be fully realized. At the same time, it is necessary to formulate a system of indicators to assess the effectiveness of such support, and on its basis, a set of measures that use the entire spectrum of direct, indirect and intermediated influence on the agro-industrial complex to obtain the maximum and sustainable positive effect.

\section{References}

[1] Agro-industrial complex of Russiain. Moscow: Ministry of agricult., 2019, 536 p.

[2] B.B. Basaev et al. "State support as the basis for the sustainable development of the regional agriculture", Bull. of Gorskiy state agrar. Univer., vol. 52, no. 3, pp. 180-187, 2015.

[3] A. Bonfiglio, R. Henke, F. Pierangeli et al., "Effects of redistributing policy support on farmers' technical efficiency", Agricult. Econ., vol. 51, no. 2, pp. 305-320, 2019.

[4] W.O. Fawole, B. Ozkan, "Examining the willingness of youths to participate in agriculture to halt the rising rate of unemployment in South Western Nigeria", J. of Econ. Studies, vol. 46, no. 3, pp. 578-590, 2019.

[5] R.S. Ferguson, S.T. Lovell, "Diversification and labor productivity on US permaculture farms", Renewable Agricult. and Food Syst., vol. 34 no. 4, pp. 326-337, 2019.

[6] R. Home, A. Indermuehle, A. Tschanz et al., "Factors in the decision by Swiss farmers to convert to organic farming", Renewable Agricult. and Food Syst., vol. 34, no. 6, pp. 571-581, 2019.

[7] E.F. Kartashov, State regulation of the international economic activity of the regional agro-industrial complex (Cand. Dissertation thesis). Kazan, 2013, 19 p.

[8] S. Lurie, C.A. Brekken, "The role of local agriculture in the new natura resource economy (NNRE) for rural economic development", Renewable Agricult. and Food Syst., vol. 34, no. 5, pp. 395-405, 2019.

[9] T. Malone, K. Gomez, "Hemp in the United States: A Case Study of Regulatory Path Dependence", Appl. Econ. Perspect. and Policy, vol. 41, no, 2, pp. 199-214, 2019.

[10] O.N. Mikhailyuk, "Forms of the state support of the economic entities in AIC", Econ. of agricult. and proc. companies, no 7, pp. 36-39, 2009.

[11] T.M. Polushkina, Development of the theory and methodology of the state regulation of the agrarian sphere of the economy (Doct. Dissertation thesis). Saransk, 2010, 28 p.

[12] R. Rupnik, M. Kukar, P. Vracar et al., "AgroDSS: A decision support system for agriculture and farming", Comp. and Electr. in Agricult. vol. 161, no. SI, pp. 260-271, 2019.

[13] I.Yu. Soldatova, "State support of the investment and innovative development of agriculture", Institut. transform. of the econ.: Russ. vector of the new industrializati., pp. 456-462, 2015 [Proc. conf. in 2 volumes] Omsk

[14] J. Strube, "Pockets of peasantness: small-scale agricultural producers in the Central Finger Lakes region of upstate New York", Agricult. and Human Values, vol. 34, no. 4, SI, pp. 837-848, 2019.

[15] N.F. Vernigor, "State support of agriculture as an integral part of the state regulation", Bull. of Altay state agrar. Univer., vol. 2, no. 124, pp. 143-147, 2015. 